L. Yu. Tomarovska, S. V. Baiurka, S. A. Karpushyna

National University of Pharmacy

\title{
Development of the UV-spectrophotometric and extraction- spectrophotometric methods of the atomoxetine quantitative determination suitable for the chemical and toxicological analysis
}

The acute and lethal antidepressant poisonings have the tendency to grow, therefore, development of the methods for its chemical and toxicological analysis is a topical issue.

Aim. To develop and validate the methods for the quantitative determination of atomoxetine, an antidepressant, using available and widely spread methods in the chemical and toxicological analysis practice, such as UV spectrophotometry and extraction-spectrophotometry in the visible region of the spectrum with methyl orange, an acidic azo dye.

Materials and methods. Absorbance values of the solutions in the UV and visible regions of the spectrum were measured on a SF-46 spectrophotometer (LOMO), the spectral measurement range was from 190 to $1100 \mathrm{~nm}$. The standard solution of atomoxetine in $0.1 \mathrm{M}$ hydrocloric acid $(300 \mu \mathrm{g} / \mathrm{ml})$ was used for the UV spectrophotometric study, and the standard solution of atomoxetine in water $(150 \mu \mathrm{g} / \mathrm{ml})$ was used for the extraction spectrophotometry in the visible region.

Results and discussion. The calibration curve for the UV spectrophotometric method was described by the equation of $y=\left(0.00455 \pm 4 \cdot 10^{-5}\right) x+(0.016 \pm 0.005)$; linearity was observed within the atomoxetine concentration range of $15.0-210 \mu \mathrm{g} / \mathrm{ml} ; L O D$ and $L O Q$ were $1.8 \mu \mathrm{g} / \mathrm{ml}$ and $5.6 \mu \mathrm{g} / \mathrm{ml}$, respectively. The calibration curve for the extraction spectrophotometric method was described by the equation of $y=\left(0.00808 \pm 5 \cdot 10^{-5}\right) x$; linearity was observed within the atomoxetine concentrations of $15.0-150.0 \mu \mathrm{g}$ in a sample; $L O D$ and $L O Q$ were $1.4 \mu \mathrm{g}$ and $4.3 \mu \mathrm{g}$ in a sample, respectively.

Conclusions. The methods developed for the quantitative determination of atomoxetine using the UV-spectrophotometric method and extraction spectrophotometry in the visible region of the spectrum satisfy the requirements set to the methods recommended for use in the forensic toxicology, and it has been confirmed by the validation characteristics.

Key words: atomoxetine; UV-spectrophotometry; extraction spectrophotometry in the visible region of the spectrum

Л. Ю.Томаровська, С. В. Баюрка, С. А. Карпушина

\section{Розробка УФ-спектрофотометричного та екстракційно-спектрофотометричного методів кількісного визначення атомоксетину, придатних для хіміко- токсикологічного аналізу}

Кількість гострих та летальних отруєнь лікарськими препаратами антидепресивної дії має тенденцію до зростання, що робить актуальним розробку методів їх хіміко-токсикологічного аналізу.

Метою даних досліджень $є$ розробка і валідація методик кількісного визначення антидепресанта атомоксетину за допомогою доступних та широко впроваджених у практику хіміко-токсикологічного аналізу методів УФ-спектрофотометрії та екстракційної спектрофотометрії у видимій області спектра з кислотним азобарвником метиловим оранжевим.

Матеріали та методи. Світлопоглинання розчинів в УФ- та видимій областях спектра вимірювали на спектрофотометрі СФ-46 (ЛОМО), спектральний діапазон вимірювань - від 190 до 1100 нм. Використовували стандартний розчин атомоксетину в 0,1 М кислоті хлоридній (300 мкг/мл) для УФ-спектросротометричних досліджень і стандартний розчин атомоксетину у воді (150 мкг/мл) для досліджень методом екстракційної спектрофотометрії у видимій області.

Результати та їх обговорення. Калібрувальний графік для УФ-спектрофотометричного методу описувався рівнянням: $y=\left(0,00455 \pm 4 \cdot 10^{-5}\right) x+(0,016 \pm 0,005)$; лінійність спостерігали в межах концентрацій атомоксетину 15,0-210 мкг/мл; LOD та LOQ становили, відповідно, 1,8 мкг/мл та 5,6 мкг/мл. Калібрувальний графік для екстракційно-спектрофотометричного методу описувався рівнянням: $y=\left(0,00808 \pm 5 \cdot 10^{-5}\right) x$; лінійність спостерігали в межах концентрацій атомоксетину 15,0-150,0 мкг в пробі; $L O D$ та $L O Q$ становили, відповідно, 1,4 мкг та 4,3 мкг в пробі.

Висновки. Розроблені методики кількісного визначення атомоксетину з використанням УФ-спектрофотометричного методу та екстракційної спектрофотометрії у видимій області спектра задовольняють вимогам щодо методів, рекомендованих для використання в судовій токсикології, що підтверджено валідаційними характеристиками.

Ключові слова: атомоксетин; УФ-спектрофотометрія; екстракційна спектрофотометрія у видимій області спектра 


\section{Л. Ю.Томаровская, С. В. Баюрка, С. А. Карпушина}

\section{Разработка УФ-спектрофотометрического и экстракционно- спектрофотометрического методов количественного определения атомоксетина, пригодных для химико-токсикологического анализа}

Количество острых и летальных отравлений лекарственными препаратами антидепрессивного действия имеет тенденцию к росту, что делает актуальным разработку методов их химико-токсикологического анализа.

Целью данных исследований является разработка и валидация методик количественного определения антидепрессанта атомоксетина с помощью доступных и широко внедренных в практику химико-токсикологического анализа методов УФ-спектрофотометрии и экстракционной спектрофотометрии в видимой области спектра с кислотным азокрасителем метиловым оранжевым.

Материалы и методы. Светопоглощение растворов в УФ- и видимой областях спектра измеряли на спектрофотометре СФ-46 (ЛОМО), спектральный диапазон измерений - от 190 до 1100 нм. Использовали стандартный раствор атомоксетина в 0,1 М кислоте хлоридной (300 мкг/мл) для УФ-спектрофотометрических исследований и стандартный раствор атомоксетина в воде (150 мкг/мл) для исследований методом экстракционной спектрофотометрии в видимой области.

Результаты и их обсуждение. Калибровочный график для УФ-спектрофротометрического метода описывался уравнением: $y=\left(0,00455 \pm 4 \cdot 10^{-5}\right) x+(0,016 \pm 0,005) ;$ линейность наблюдали в пределах концентраций атомоксетина 15,0-210 мкг/мл; LOD и LOQ составили, соответственно, 1,8 мкг/мл и 5,6 мкг/мл. Калибровочный график для экстракционно-спектрофотометрического метода описывался уравнением: $y=\left(0,00808 \pm 5 \cdot 10^{-5}\right) x$; линейность наблюдали в пределах концентраций атомоксетина 15,0-150,0 мкг в пробе; LOD и LOQ составили, соответственно, 1,4 мкг и 4,3 мкг в пробе.

Выводы. Разработанные методики количественного определения атомоксетина с использованием УФспектрофотометрического метода и экстракционной спектрофотометрии в видимой области спектра удовлетворяют требованиям к методам, рекомендованным для использования в судебной токсикологии, что подтверждено валидационными характеристиками.

Ключевые слова: атомоксетин; УФ-спектрофотометрия; экстракционная спектрофотометрия 8 видимой области спектра

Atomoxetine ((3R)- $N$-methyl-3-(2-methylphenoxy)3-phenylpropan-1-amine hydrochloride) is an antidepressant drug used in the treatment of attention deficit hyperactivity syndrome, as well as the therapeutically resistant depression [1]. Repeated episodes of acute and lethal atomoxetine poisoning were registered $[2,3,4]$. The postmortem atomoxetine concentrations were within the following limits: arterial blood $-0.1-8.3 \mathrm{mg} / \mathrm{l}$; bile $1.0-33 \mathrm{mg} / 1$; urine $-0.1 \mathrm{mg} / 1$; liver $-0.44-29 \mathrm{mg} / \mathrm{kg}$ [4]

The methods of atomoxetine determination in the blood plasma using high-performance liquid chromatography with UV- [5, 6], fluorescence [7], mass spectrometry detection [8], or capillary electrophoresis [9] have been developed. These methods of analysis are highly sensitive and specific, but require careful sample preparation and special expensive equipment; as a result, they are not always available.

Methods of molecular absorption spectroscopy in the $\mathrm{UV}$ and visible region of the spectrum allow determining the toxic and lethal concentrations of toxicants in the biological samples and can be recommended for use in the forensic toxicology $[10,11,12]$.

The aim of the study was to develop and validate the methods for the quantitative determination of atomoxetine, an antidepressant, using available and widely spread methods in the chemical and toxicological analysis practice, such as UV spectrophotometry and extraction-spectrophotometry in the visible region of the spectrum with methyl orange, an acidic azo dye.

\section{Materials and methods}

The pure substance of atomoxetine isolated by the method described in the article [13] from the medicine "Strattera" (7 capsules, $60 \mathrm{mg}$ ) produced by "Lilly" (Czech Republic) was used for the study.

Absorbance values of the solutions in the UV and visible regions of the spectrum were measured on a SF-46 spectrophotometer (LOMO), the spectral measurement range was from 190 to $1100 \mathrm{~nm}$.

Buffer solution $\mathrm{pH}$ was monitored by a $\mathrm{pH}$-meter 5123 (Elvro, Wroclaw, Poland).

The following glassware was used: $10.0 \mathrm{ml}, 50.0 \mathrm{ml}$ volumetric flasks, volumetric pipettes, Class A (Simax, Czech Republic).

All other chemicals were of analytical grade or better.

The method of the calibration curve construction for the UV spectrophotometric determination. Prepare the stock solution (SS) and six working standard solutions (WSS) of atomoxetine hydrochloride $(m=6)$ in $0.1 \mathrm{M}$ hydrochloric acid. For this purpose dissolve $0.01715 \mathrm{~g}$ of atomoxetine hydrochloride (corresponding to $0.01500 \mathrm{~g}$ of the atomoxetine base) in $50.0 \mathrm{ml}$ of $0.1 \mathrm{M}$ hydrochloric acid using a $50.0 \mathrm{ml}$ volumetric flask (the concentration of the resulting SS is $300 \mu \mathrm{g} / \mathrm{ml}$ of the atomoxetine base). Then place $0.50 ; 1.00 ; 2.00 ; 3.0 ; 4.0$; $5.0 ; 6.0$ and $7.0 \mathrm{ml}$ of SS into a $10.0 \mathrm{ml}$ volumetric flask and dilute to the volume with $0.1 \mathrm{M}$ hydrochloric acid (the concentrations of the resulting WSS are of 15.0; 30.0; $60.0 ; 90 ; 120 ; 150 ; 180$ and $210 \mu \mathrm{g} / \mathrm{ml}$ of the atomoxe- 
The accuracy and precision of the UV spectrophotometric method (intra day)

\begin{tabular}{|c|c|c|c|c|c|c|c|}
\hline $\begin{array}{c}\text { Introduced, } \\
\mu \mathrm{g} / \mathrm{ml}\end{array}$ & Absorbance & Found, $\mu \mathrm{g} / \mathrm{ml}$ & Found/introduced, $\%$ & Average, $\%$ & SD & $R S D, \%$ & $\varepsilon, \%$ \\
\hline \multirow{3}{*}{15} & 0.084 & 14.95 & 99.63 & \multirow{3}{*}{99.07} & \multirow{3}{*}{0.970} & \multirow{3}{*}{0.98} & \multirow{3}{*}{2.43} \\
\hline & 0.084 & 14.95 & 99.63 & & & & \\
\hline & 0.083 & 14.69 & 97.95 & & & & \\
\hline \multirow{3}{*}{90} & 0.430 & 91.00 & 101.10 & \multirow{3}{*}{100.77} & \multirow{3}{*}{0.783} & \multirow{3}{*}{0.78} & \multirow{3}{*}{1.93} \\
\hline & 0.425 & 89.89 & 99.88 & & & & \\
\hline & 0.431 & 91.21 & 101.34 & & & & \\
\hline \multirow{3}{*}{180} & 0.827 & 178.24 & 99.02 & \multirow{3}{*}{99.19} & \multirow{3}{*}{0.511} & \multirow{3}{*}{0.52} & \multirow{3}{*}{1.28} \\
\hline & 0.833 & 179.56 & 99.76 & & & & \\
\hline & 0.825 & 177.80 & 98.78 & & & & \\
\hline
\end{tabular}

tine base, respectively). Measure the absorbance values of WSS at a wavelength of $270 \mathrm{~nm}$ in a $10 \mathrm{~mm}$ light pathway cuvette. Use $0.1 \mathrm{M}$ hydrochloric acid as a reference solution. Examine each WSS twice $(n=2)$.

The method of the calibration curve construction for the quantitative determination by the extraction spectrophotometry in the visible region of the spectrum. Prepare the stock solution (SS) of atomoxetine hydrochloride in water. For this purpose dissolve $0.01715 \mathrm{~g}$ of atomoxetine hydrochloride (corresponding to $0.01500 \mathrm{~g}$ of the atomoxetine base) in $100.0 \mathrm{ml}$ of distilled water using a $100.0 \mathrm{ml}$ volumetric flask (the concentration of the resulting SS is $150 \mu \mathrm{g} / \mathrm{ml}$ of the atomoxetine base). Study six calibrators with a different drug content $(m=6)$, examining each three times $(n=3)$. For this purpose place $5.0 \mathrm{ml}$ of acetate buffer with $\mathrm{pH} 4.6,5.0 \mathrm{ml}$ of $0.05 \%$ methyl orange solution and $0.1 ; 0.2 ; 0.3 ; 0.4 ; 0.6$ and $1.0 \mathrm{ml}$ of SS (the resulting solutions contain 15.0; 30.0; $45.0 ; 60.0 ; 90.0$ and $15.0 \mu \mathrm{g}$ of the atomoxetine base in a sample, respectively). Add in all cases, except the last one, the appropriate volumes of distilled water (from 0.90 to $0.40 \mathrm{ml}$ ) with the constant volume of the aqueous phase. Add $15.0 \mathrm{ml}$ of chloroform to the mixtures obtained. Shake the mixtures using the separating funnels for 10 min with the help of a mechanical shaker and left for $10 \mathrm{~min}$ for separating the layers. Collect $14 \mathrm{ml}$ of the resulting chloroform layers discarding the first portions (about $1 \mathrm{ml}$ ), then add to the chloroform layers $2 \mathrm{ml}$ of $1 \%$ sulphuric acid solution in absolute ethanol.
Mix the solutions obtained thoroughly and measure the absorbance values at $\lambda_{\max }=540 \mathrm{~nm}$ in a $10 \mathrm{~mm}$ light pathway cuvette. Use the blank solution as a reference.

\section{Results and discussion}

The absorbance values in the UV region of the spectrum for eight SSR of atomoxetine $(m=8 ; n=2)$ were processed by the linear regression model described in the general form as $y=b x+a$. The significance of the regression coefficient $a$ in the regression model was checked using the F-test [14], and the conclusion was drawn that it was impossible to have the equation in the form of $y=b^{\prime} x$. Thus, the calibration curve was described by the equation of $y=\left(0.00455 \pm 4 \cdot 10^{-5}\right) x+(0.016 \pm 0.005)$ $\left(r=0.999 ; S_{o}{ }^{2}=3 \cdot 10^{-5} ; S_{a}=2.49 \cdot 10^{-3} ; S_{b}=4 \cdot 10^{-5}\right)$. Atomoxetine showed linearity in the range of $15.0-210 \mu \mathrm{g} / \mathrm{ml}$. The $L O D$ and $L O Q$ values were calculated using standard deviation of intercept $\left(S_{a}\right)$ in accordance with the relevant equations: $L O D=3.3 \cdot S_{a}^{2} / b$ and $L O Q=10 \cdot S_{a}^{2} / b$ $[15,16]$. They were $1.8 \mu \mathrm{g} / \mathrm{ml}$ and $5.5 \mu \mathrm{g} / \mathrm{ml}$, respectively.

The accuracy and precision of the method were determined at three concentration levels within one day (intra day) (Tab. 1) and over three consecutive days (inter day). The number of replicates per a concentration level and day was three.

The "inter day" accuracy and precision were $99.23 \%$ $(R S D=0.83 \%)$ at the low concentration level of the analyte, $100.88 \%(R S D=0.41 \%)$ at the middle concentration level, $99.28 \%(R S D=0.21 \%)$ at the high concentration level.

Table 2

The accuracy and precision of the extraction spectrophotometric method (intra day)

\begin{tabular}{|c|c|c|c|c|c|c|c|}
\hline Introduced, $\mu \mathrm{g}$ & Absorbance & Found, $\mu \mathrm{g}$ & Found/introduced, $\%$ & Average, $\%$ & SD & $R S D, \%$ & $\varepsilon, \%$ \\
\hline \multirow{3}{*}{15} & 0.120 & 14.85 & 99.01 & \multirow{3}{*}{101.21} & \multirow{3}{*}{2.074} & \multirow{3}{*}{2.05} & \multirow{3}{*}{5.09} \\
\hline & 0.125 & 15.47 & 103.13 & & & & \\
\hline & 0.123 & 15.22 & 101.49 & & & & \\
\hline \multirow{3}{*}{60} & 0.485 & 60.02 & 100.04 & \multirow{3}{*}{100.43} & \multirow{3}{*}{1.450} & \multirow{3}{*}{1.44} & \multirow{3}{*}{3.59} \\
\hline & 0.480 & 59.41 & 99.00 & & & & \\
\hline & 0.494 & 61.14 & 101.90 & & & & \\
\hline \multirow{3}{*}{150} & 1.223 & 15.36 & 100.91 & \multirow{3}{*}{99.59} & \multirow{3}{*}{1.460} & \multirow{3}{*}{1.47} & \multirow{3}{*}{3.63} \\
\hline & 1.188 & 14.03 & 98.02 & & & & \\
\hline & 1.210 & 149.75 & 99.83 & & & & \\
\hline
\end{tabular}


The absorbance values in the visible region of the spectrum for six calibration standards of atomoxetine $(m=6 ; n=3)$ were processed by the linear regression model. The significance of the regression coefficient $a$ in the regression model was checked using the F-test [14], and the conclusion was drawn that it was possible to have the equation in the form of $y=b^{\prime} x$. Thus, the calibration curve was described by the equation of $y=\left(0.00808 \pm 5 \cdot 10^{-5}\right) x\left(r=0.999 ; S_{o}^{2}=7 \cdot 10^{-5}\right.$; $\left.S_{a}=3.5 \cdot 10^{-3} ; S_{b}=5 \cdot 10^{-5}\right)$. Atomoxetine showed linearity in the range of 15.0-150.0 $\mu \mathrm{g}$ in a sample. The $L O D$ and $L O Q$ values were calculated using standard deviation of intercept and the slope of the calibration curve $[15,16]$. They were $1.4 \mu \mathrm{g}$ and $4.3 \mu \mathrm{g}$ in a sample, respectively (Tab. 2).
The "inter day" accuracy and precision were $101.39 \%$ $(R S D=2.18 \%)$ at the low concentration level of the analyte, $100.08 \%(R S D=0.81 \%)$ at the middle concentration level, $99.84 \%(R S D=1.05 \%)$ at the high concentration level.

\section{CONCLUSIONS}

The methods developed for the quantitative determination of atomoxetine using the UV-spectrophotometric method and extraction spectrophotometry in the visible region of the spectrum satisfy the requirements set to the methods recommended for use in the forensic toxicology $[12,16]$, and it has been confirmed by the validation characteristics.

Conflict of Interests: authors have no conflict of interests to declare.

\section{REFERENCES}

1. A systematic review of combination therapy with stimulants and atomoxetine for attention-deficit/hyperactivity disorder, including patient characteristics, treatment strategies, effectiveness, and tolerability / T. Treuer, S. S. Gau, L. Méndez et al. // J. Child Adolesc. Psychopharmacol. - 2013. - Vol. 23, Issue 3. - P. 179-193. doi: 10.1089/cap.2012.0093

2. Paxton, G. A. Acute suicidality after commencing atomoxetine / G. A. Paxton, N. E Cranswick // J. Paediatr. Child Health. - 2008. - Vol. 44, Issue 10. - P. 596-598. doi: 10.1111/j.1440-1754.2008.01389.x

3. Garside, D. Postmortem tissue distribution of atomoxetine following fatal and nonfatal doses - three case reports / D. Garside, J. D. RoperoMiller, E. C. Riemer // J. Forensic Sci. - 2006. - Vol. 51, Issue 1. - P. 179-182. doi: 10.1111/j.1556-4029.2005.00021.x

4. Clarke's analysis of drugs and poisons in pharmaceuticals, body fluids and postmortem material : 4-th ed. / ed. by A. C. Moffat, M. D. Osselton, B. Widdop. - London, Chicago : Pharmaceutical Press, 2011. - 2736 p.

5. A new high performance liquid chromatographic method for quantification of atomoxetine in human plasma and its application for pharmacokinetic study / C. Patel, M. Patel, S. Rani et al. // J. Chromatogr. B Analyt. Technol. Biomed. Life Sci. - 2007. - Vol. 850, Issue 1-2. P. 356-360. doi: 10.1016/j.jchromb.2006.12.011

6. Determination of atomoxetine in human plasma by a high performance liquid chromatographic method with ultraviolet detection using liquid-liquid extraction / W. Guo, W. Li, G. Guo et al. // J. Chromatogr. B Analyt. Technol. Biomed. Life Sci. - 2007. - Vol. 854, Issue 1-2. P. 128-134. doi: 10.1016/j.jchromb.2007.04.007

7. Sensitive quantification of atomoxetine in human plasma by HPLC with fluorescence detection using 4-(4,5-diphenyl-1H-imidazole-2-yl) benzoyl chloride derivatization / H. J. Zhu, J. S. Wang, J. L. Donovan et al. // J. Chromatogr. B Analyt. Technol. Biomed. Life Sci. - 2007. - Vol. 846, Issue 1-2. - P. 351-354. doi: 10.1016/j.jchromb.2006.08.019

8. A liquid chromatography/tandem mass spectrometry assay for the analysis of atomoxetine in human plasma and in vitro cellular samples / D. I. Appel, B. Brinda, J. S. Markowitz et al. // Biomed. Chromatogr. - 2012. - Vol. 26, Issue 11. - P. 1364-1370. doi: 10.1002/bmc.2706

9. Capillary electrophoresis coupled with electrochemiluminescence for determination of atomoxetine hydrochloride and the study on its interactions with three proteins / H. J. Zeng, R. Yang, Y. Zhang et al. // Luminescence. - 2014. - Vol. 30, Issue 2. - P. 124-130. doi: 10.1002/bio.2700

10. Clarke's Analytical Forensic Toxicology / ed. by Sue Jickells, Adam Negrusz. - London : Pharmaceutical Press, 2008. - 648 p.

11. Вергейчик, Т. Х. Токсикологическая химия / Т. Х. Вергейчик. - М. : МЕДпресс-информ, 2009. - 400 c.

12. Guidance for the Validation of Analytical Methodology and Calibration of Equipment used for Testing of Illicit Drugs in Seized Materials and Biological Specimens / United Nations Office on Drugs and Crime (Vienna). - New York, 2009. - 67 p.

13. Tomarovska, L. Yu. Development of the methods for atomoxetine identification suitable for the chemical and toxicological analysis / L. Yu. Tomarovska, S. V. Baiurka, S. A. Karpushyna // Вісник фармації. - 2017. - № 2 (90). - C. 13-20. doi: 10.24959/nphj.17.2154.

14. Аналітична хімія : навч. посіб. для фармац. ВНЗ та ф-тів III-IV рівнів акредитації / В. В. Болотов, О. М. Свєчнікова, С. В. Колісник та ін. - Х. : НФаУ, 2004. - 480 с.

15. Державна фармакопея України. Доп. 2. / Державне підприємство «Науково-експертний фармакопейний центр». - 1-е вид. - X. : Науково-експертний фармакопейний центр, 2008. - 620 с.

16. SOFT / AAFS Forensic Laboratory Guidelines. - 2006. - 24 p. - [Электронный pecypc]. - Available at : http://www.soft-tox.org/files/ Guidelines_2006_Final.pdf

\section{REFERENCES}

1. Treuer, T., Gau, S. S.-F., Méndez, L., Montgomery, W., Monk, J. A., Altin, M., Dueñas, H. J. (2013). A Systematic Review of Combination Therapy with Stimulants and Atomoxetine for Attention-Deficit/Hyperactivity Disorder, Including Patient Characteristics, Treatment Strategies, Effectiveness, and Tolerability. Journal of Child and Adolescent Psychopharmacology, 23 (3), 179-193. doi: 10.1089/ cap.2012.0093

2. Paxton, G. A., Cranswick, N. E. (2008). Acute suicidality after commencing atomoxetine. Journal of Paediatrics and Child Health, 44 (10), 596-598. doi: 10.1111/j.1440-1754.2008.01389.x 
3. Garside, D., Ropero-Miller, J. D., Riemer, E. C. (2006). Postmortem Tissue Distribution of Atomoxetine Following Fatal and Nonfatal Doses-Three Case Reports. Journal of Forensic Sciences, 51 (1), 179-182. doi: 10.1111/j.1556-4029.2005.00021.x

4. Moffat, A. C., Osselton, M. D., Widdop B., Clarke, E. G. C. (2011). Clarke's analysis of drugs and poisons in pharmaceuticals, body fluids and postmortem material, (4-th ed.). London, Chicago : Pharmaceutical Press, 2736.

5. Patel, C., Patel, M., Rani, S., Nivsarkar, M., Padh, H. (2007). A new high performance liquid chromatographic method for quantification of atomoxetine in human plasma and its application for pharmacokinetic study. Journal of Chromatography B, 850 (1-2), 356-360. doi: 10.1016/j.jchromb.2006.12.011

6. Guo, W., Li, W., Guo, G., Zhang, J., Zhou, B., Zhai, Y., Wang, C. (2007). Determination of atomoxetine in human plasma by a high performance liquid chromatographic method with ultraviolet detection using liquid-liquid extraction. Journal of Chromatography B, 854 (1-2), 128-134. doi: 10.1016/j.jchromb.2007.04.007

7. Zhu, H.-J., Wang, J.-S., Donovan, J. L., DeVane, C. L., Gibson, B. B., Markowitz, J. S. (2007). Sensitive quantification of atomoxetine in human plasma by HPLC with fluorescence detection using 4-(4,5-diphenyl-1H-imidazole-2-yl) benzoyl chloride derivatization. Journal of Chromatography B, 846 (1-2), 351-354. doi: 10.1016/j.jchromb.2006.08.019

8. Appel, D. I., Brinda, B., Markowitz, J. S., Newcorn, J. H., Zhu, H.-J. (2012). A liquid chromatography/tandem mass spectrometry assay for the analysis of atomoxetine in human plasma andin vitrocellular samples. Biomedical Chromatography, 26 (11), $1364-1370$. doi: 10.1002/bmc.2706

9. Zeng, H., Yang, R., Zhang, Y., Li, J., Qu, L. (2014). Capillary electrophoresis coupled with electrochemiluminescence for determination of atomoxetine hydrochloride and the study on its interactions with three proteins. Luminescence, 30 (2), 124-130. doi: 10.1002/bio.2700

10. Jickells, S., Negrusz, A. (2008). Clarke's Analytical Forensic Toxicology. London : Pharmaceutical Press. 648.

11. Vergeichik, T. Kh. (2009). Toksikologicheskaia khimiia. Moscow : MEDpress-inform, 400.

12. Guidance for the Validation of Analytical Methodology and Calibration of Equipment used for Testing of Illicit Drugs in Seized Materials and Biological Specimens. (2009). New York: United Nations Office on Drugs and Crime (Vienna), 67.

13. Tomarovska, L. Y., Baiurka, S. V., Karpushyna, S. A. (2017). Development of the methods for atomoxetine identification suitable for the chemical and toxicological analysis. Visnik Farmaciï, 2 (90), 13-20. doi: 10.24959/nphj.17.2154

14. Bolotov, V. V., Sviechnikova, O. M., Kolisnyk, S. V., Zhukova, T. V., Sych, Yu. V., Dynnyk, K. V., Zarechenskyi, M. A., Mykytenko, O. Ye., Hryzodub, O. I., Terno, I. S. (2004). Analitychna khimiia. Kharkiv: NUPh, 480.

15. Derzhavna Farmakopeia Ukrainy, 1-st ed. (2008). Kharkiv: Naukovo-ekspertnyi farmakopeinyi tsentr, 620.

16. SOFT/AAFS Forensic Laboratory Guidelines. (2006). Available at: http://www.soft-tox.org/files/Guidelines_2006_Final.pdf

\section{Information about authors:}

Tomarovska L. Yu., teaching assistant of the Physical and Colloid Chemistry Department, National University of Pharmacy. E-mail: 10639584807@gmail.com Baiurka S. V., Doctor of Pharmacy (Dr. habil.), associate professor, head of the Drug and Analytical Toxicology Department, National University of Pharmacy. E-mail: bayurka.sergii@gmail.com

Karpushyna S. A., Candidate of Chemistry (Ph.D.), associate professor of the Drug and Analytical Toxicology Department, National University of Pharmacy.

E-mail: svitkrp@gmail.com

Відомості про авторів:

Томаровська Л. Ю., асистент кафедри фізичної та колоїдної хімії, Національний фармацевтичний університет. Е-таil: 10639584807@gmail.com

Баюрка С. В., д-р фарм. наук, доцент, завідувач кафедри лікарської та аналітичної токсикології, Національний фармацевтичний університет.

E-mail: bayurka.sergii@gmail.com

Карпушина С. А., канд. хім. наук, доцент кафедри лікарської та аналітичної токсикології, Національний фармацевтичний університет.

E-mail: svitkrp@gmail.com

Сведения об авторах:

Томаровская Л. Ю., ассистент кафедры физической и коллоидной химии, Национальный фармацевтический университет. Е-таil: 10639584807@gmail.сот Баюрка С. В., д-р фарм. наук, доцент, заведующий кафедрой лекарственной и аналитической токсикологии, Национальный фармацевтический университет. E-mail: bayurka.sergii@gmail.com

Карпушина С. А., канд. хим. наук, доцент кафедры лекарственной и аналитической токсикологии, Национальный фармацевтический университет. E-mail: svitkrp@gmail.com 